\title{
Om as familie in Suid-Afrika te leef: Interkulturele Bybelstudie as transformatiewe krag in die samelewing
}

NGTT DEEL 55, NO 1, 2014

\section{Jonker, Louis}

Universiteit Stellenbosch

\begin{abstract}
Living as a family in South Africa: Intercultural Bible study as a transformational power in society

This contribution describes a research project in empirical hermeneutics which departed from the hypothesis that a development of hermeneutical skills among Christian communities for reading the Bible together with "the Other" could contribute significantly towards the fostering of interculturality in the broader South African society. ${ }^{1}$ Additionally, it was hypothesized that the studying of the dynamics of intercultural Bible reading could provide us with better insight into the dynamics of a shift from multiculturality to interculturality. ${ }^{2}$ The present article reports on the results achieved in the investigation. It has been established that fear for and a lack of knowledge of "the Other" are important reasons for the lack of interculturality in society. It has also been confirmed that the Bible - as liminal "meeting place" for people from different cultures - can foster a sense of family and hospitality in the South African nation.
\end{abstract}

1 Die projek is befonds deur die Nasionale Navorsingstigting (NNS). Dank word hiermee uitgespreek vir die fondse wat beskikbaar gestel is. Sienings wat hier uitgespreek word, bly egter die verantwoordelikheid van die outeur.

2 Sien vorige publikasies hieroor waarin die uitgangspunte van die projek beskryf is: Jonker (2006 en 2007).

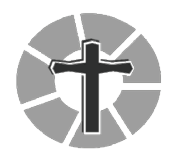




\section{INLEIDING}

Die nuwe politieke bedeling in Suid-Afrika wat met die vrylating van Nelson Mandela uit die gevangenis in Februarie 1990 ingelui is, het 'n nuwe erkenning van die diversiteit van kulture, tale en godsdienste in die land meegebring. Die berugte sukses van die apartheidsideologie as 'n proses van sosiale ingenieurswese het veral gelê in die miskenning van kulturele verskeidenheid. Die interaksie in die samelewing is gereguleer in terme van vier "rassegroepe", naamlik wit, swart, kleurling en Indiërs. Sedert die koms van die nuwe bedeling het die situasie verander. Die erkenning van die diversiteit van kulture, tale en godsdienste het een van die boustene van die nuwe demokrasie geword. As in die algemeen geoordeel word, het Suid-Afrika reeds enorme vordering gemaak sedert 1990 met die aanvaarding van die multikulturaliteit van die samelewing. ${ }^{3}$

In 'n empiries-hermeneutiese navorsingsprojek wat in die afgelope jare in die Wes-Kaapprovinsie van Suid-Afrika onderneem is, is egter geargumenteer dat 'n beweging na interkulturaliteit nie noodwendig in dieselfde tydperk plaasgevind het nie. Hoewel daar voorbeelde op kleinskaal sal wees wat enige veralgemening sal ondermyn, kan dit met vertroue beweer word dat die Suid-Afrikaanse nasie hulself nie as 'n "familie" beskou nie (om Desmond Tutu se woorde te gebruik). ${ }^{4}$

In 'n kleinskaalse navorsingsprojek deur navorsers aan die Universiteit van Stellenbosch is gepoog om 'n bydrae met betrekking tot hierdie situasie te maak. Die teoretiese uiteensetting wat in 'n vorige publikasie voorsien is, word nie hier herhaal nie. ${ }^{5}$ Die bedoeling van hierdie bydrae is eerder om 'n beskrywing te gee van die proses wat gevolg is in die empiriese studie, en om aan te dui watter resultate in die ondersoek behaal is. ${ }^{6}$ Die bydrae sal afsluit met 'n aantal waarnemings oor hoe interkulturele Bybelleespraktyke as 'n alternatiewe krag tot verandering 'n bydrae kan maak om interkulturaliteit in die Suid-Afrikaanse samelewing te fasiliteer.

3 Die term "multikulturaliteit" verwys na die vreedsame of nie-vreedsame naasbestaan van verskillende kultuurgroepe in een samelewing, met min of geen interaksie tussen die kultuurgroepe. "Interkulturaleit" veronderstel egter 'n doelbewuste poging om verryk te word deur interaksie tussen kultuurgroepe, op weg na 'n samelewing wat die kulturele verskeidenheid as bate ervaar en benut.

4 Sien Tutu (2004).

5 Sien Jonker (2007).

6 Hierdie artikel wil ook 'n bydrae lewer deur die wyse van verslagdoening tot die ontwikkeling van die relatief nuwe veld van empiriese hermeneutiek. Die veld word veral deur prof. Dr. Hans de Wit van die Vrije Universiteit in Amsterdam gepropageer. Sien, tesame met ander publikasies van De Wit, sy opsomming in De Wit (2004:477492). 


\section{2. 'n KLEINSKAALSE WAARNEMING}

\subsection{Die deelnemende groepe}

Die empiriese studie in hierdie navorsingsprojek is as 'n geval-georiënteerde kwalitatiewe data-analise ingerig. Babbie (2004:370) beskryf kwalitatiewe dataanalise as "the non-numerical examination and interpretation of observations for the purpose of discovering underlying meanings and patterns of relationships." 'n Geval-georiënteerde analise het dus ten doel om 'n grondige verstaan van die rol van veranderlikes in 'n beperkte aantal gevalle te bekom.

Agt groepe is geïdentifiseer wat gedurende 2008-2009 aan die empiriese fase deelgeneem het. Hoewel diekeusevan groepe in'nkwalitatiewe studienie noodwendig gedoen word met die bedoeling om verteenwoordigend van die kulturele diversiteit in Suid-Afrika te wees nie, is die groepe so gekies dat minstens drie verskillende soorte kulturele interaksie wat in die Wes-Kaap voorkom, waargeneem kon word. Die volgende "kulturele pare" is in die studie betrek:

\subsubsection{Xhosa - Wit Afrikaans ${ }^{7}$}

Twee pare (Groepe 1 en 2, en Groepe 3 en 4) het in hierdie kategorie deelgeneem. Die volgende biografiese inligting vir elke groep ${ }^{8}$ is in die rekenaaranalise ingesluit:

7 'n Onderskeid word gemaak tussen "Wit Afrikaans" en "Bruin Afrikaans". Hierdie onderskeiding wat steeds die rassegeskiedenis van hierdie land weerspieël, dui die verskille of variasies wat binne kulture van "Wit Afrikaans" en sogenaamd "Bruin/ Kleurling Afrikaans" bestaan, aan. Hoewel die meerderheid deelnemers vanuit hierdie twee groepe 'n gemeenskaplike moedertaal het, het die apartheidverlede sosiale verskillende tussen hierdie groepe bewerkstellig wat tot vandag toe bestaan. Hierdie werklikheid is daarom in die seleksie van groepe in ag geneem.

8 Om aan die etiese afspraak tussen die ondersoeker en deelnemers te voldoen om nie die identiteit van groepe of individue bekend te maak nie, word daardie inligting nie in hierdie verslag vermeld nie.

9 Die kwalitatiewe analise van die empiriese data is met die rekenaarsagteware Atlas. TI, Weergawe 5.0.66 gedoen. Vir meer inligting oor hierdie sagteware wat spesiaal 


\section{Groep 1:}

\begin{tabular}{|l|l|}
\cline { 2 - 2 } Kulturele groep: & Xhosa \\
\hline Taal: & isiXhosa \\
\hline Groepgrootte: & $>15$ lede \\
\hline Gender-verspreiding: & Hoofsaaklik manlik \\
\hline Ouderdomsverspreiding: & Meerderheid 30-50 jaar \\
\hline Groepgeskiedenis: & $<5$ jaar \\
\hline Rede vir bestaan: & $\begin{array}{l}\text { Benodig opleiding (almal is lekepastore in hul } \\
\text { kerke) }\end{array}$ \\
\hline Self-identifisering van groep: & $\begin{array}{l}\text { Plek van onderrig/opleiding; Bybelstudiegroep; } \\
\text { Plek van opleiding vir sending }\end{array}$ \\
\hline Ontmoetingsplek: & Skool in buurt \\
\hline Denominasionele affiliasie: & $\begin{array}{l}\text { Gemeng: Meerderheid behoort aan Afrika } \\
\text { Onafhanklike Kerke - enkeles behoort aan } \\
\text { Metodiste of Pinksterkerke }\end{array}$ \\
\hline Geletterdheidsvlak: & $\begin{array}{l}\text { Gemiddeld tussen primêre en sekondêre } \\
\text { skoolvlak }\end{array}$ \\
\hline
\end{tabular}

\section{Groep 2:}

\begin{tabular}{|l|l|} 
Kulturele groep: & Wit Afrikaans \\
\hline Taal: & Afrikaans \\
\hline Groepgrootte: & 6 -10 lede \\
\hline Gender-verspreiding: & Vroulik en manlik (gelyke verdeling) \\
\hline Ouderdomsverspreiding: & Meerderheid > 50 jaar \\
\hline Groepgeskiedenis: & Nuut gestig \\
\hline Rede vir bestaan: & Vir die doel van die projek \\
\hline Self-identifisering van groep: & Wil grense oorskry na ander gelowiges \\
\hline Ontmoetingsplek: & Huis van deelnemer \\
\hline Denominasionele affiliasie: & Almal lede van die NG Kerk \\
\hline Geletterdheidsvlak: & Gemiddeld tersiêre vlak \\
\hline
\end{tabular}

\section{Groep 3:}

\begin{tabular}{|l|l|} 
Kulturele groep: & Xhosa \\
\hline Taal: & isiXhosa \\
\hline Groepgrootte: & 6 -10 lede \\
\hline Gender-verspreiding: & Vroulik \\
\hline Ouderdomsverspreiding: & Meerderheid tussen 20-40 jaar \\
\hline Groepgeskiedenis: & $>10$ jaar \\
\hline Rede vir bestaan: & Vrouevereniging in die gemeente \\
\hline Self-identifisering van groep: & Vereniging in gemeente; Plek van opleiding/opvoeding \\
\hline Ontmoetingsplek: & In die kerk van die gemeente \\
\hline Denominasionele affiliasie: & Almal lede van die VGK \\
\hline Geletterdheidsvlak: & Gemiddeld tussen primêre en sekondêre skoolvlak \\
\hline
\end{tabular}

ontwikkel is vir die doel van kwalitatiewe analises, sien www.atlasti.com. 


\section{Groep 4:}

\begin{tabular}{|l|l|} 
Kulturele groep: & Wit Afrikaans \\
\hline Taal: & Afrikaans \\
\hline Groepgrootte: & 6-10 lede \\
\hline Gender-verspreiding: & Vroulik en manlik (meerderheid vroulik) \\
\hline Ouderdomsverspreiding: & Gemiddeld <30 jaar \\
\hline Groepgeskiedenis: & Nuut gestig \\
\hline Rede vir bestaan: & $\begin{array}{l}\text { 'n Vorige groep het ontbind, en sommige lede het 'n } \\
\text { nuwe groep gestig }\end{array}$ \\
\hline Self-identifisering van groep: & Pastorale ondersteuningsgroep vir mekaar \\
\hline Ontmoetingsplek: & Huis van een van die deelnemers \\
\hline Denominasionele affiliasie: & Meerderheid lede van die NG Kerk \\
\hline Geletterdheidsvlak: & Gemiddeld tussen sekondêre en tersiêre skoolvlak \\
\hline
\end{tabular}

\subsubsection{Wit Afrikaans - Bruin Afrikaans}

Een paar (Groepe 5 en 6 ) het in hierdie kategorie deelgeneem:

\section{Groep 5:}

\begin{tabular}{|c|c|}
\hline Kulturele groep: & Wit Afrikaans \\
\hline Taal: & Afrikaans \\
\hline Groepgrootte: & 6-10 lede \\
\hline Gender-verspreiding: & Vroulik \\
\hline Ouderdomsverspreiding: & Gemiddeld tussen 40-60 jaar \\
\hline Groepgeskiedenis: & $\begin{array}{l}\text { Groep is reeds meer as } 20 \text { jaar gelede gestig; hoewel lede } \\
\text { gewissel het, is die oorspronklike kern van die groep steeds } \\
\text { teenwoordig }\end{array}$ \\
\hline Rede vir bestaan: & BybesItudie \\
\hline Self-identifisering van groep: & $\begin{array}{l}\text { Bybelstudiegroep; Plek van onderrig/opvoeding; Pastorale } \\
\text { ondersteuningsgroep vir mekaar; Uitreik na gemeenskap }\end{array}$ \\
\hline Ontmoetingsplek: & Huis van 'n deelnemers \\
\hline Denominasionele affiliasie: & Meerderheid lede van die NG Kerk \\
\hline Geletterdheidsvlak: & Gemiddeld tersiêre vlak \\
\hline
\end{tabular}




\section{Groep 6:}

\begin{tabular}{|l|l|}
\hline Kulturele groep: & Bruin Afrikaans \\
\hline Taal: & Afrikaans \\
\hline Groepgrootte: & $11-15$ lede \\
\hline Gender-verspreiding: & Vroulik en manlik (meerderheid vroulik) \\
\hline Ouderdomsverspreiding: & Gemiddeld tussen 40-60 jaar \\
\hline Groepgeskiedenis: & $<5$ jaar \\
\hline Rede vir bestaan: & $\begin{array}{l}\text { Inisiatief van gemeente om geestelike ondersteuning in } \\
\text { moeilike tye te verskaf }\end{array}$ \\
\hline Self-identifisering van groep: & $\begin{array}{l}\text { Pastorale ondersteuningsgroep; Gebedsgroep; Uitreik na } \\
\text { gemeenskap }\end{array}$ \\
\hline Ontmoetingsplek: & In die kerkgebou \\
\hline Denominasionele affiliasie: & Meerderheid behoort aan die VGK \\
\hline Geletterdheidsvlak: & Gemiddeld tussen primêre en sekondêre skoolvlak \\
\hline
\end{tabular}

\subsubsection{Xhosa - Bruin Afrikaans}

Een paar (Groepe 7 en 8) het in hierdie kategorie deelgeneem:

\section{Groep 7:}

\begin{tabular}{|l|l|} 
Kulturele groep: & Xhosa \\
\hline Taal: & isiXhosa \\
\hline Groepgrootte: & $11-15$ lede \\
\hline Gender-verspreiding: & Vroulik en manlik (meerderheid vroulik) \\
\hline Ouderdomsverspreiding: & Gemiddeld > 55 jaar \\
\hline Groepgeskiedenis: & $<5$ jaar \\
\hline Rede vir bestaan: & Behoefte aan opleiding/opvoeding; Inisiatief van kerk \\
\hline Self-identifisering van groep: & Plek van opleiding/opvoeding; Bybelstudiegroep \\
\hline Ontmoetingsplek: & Publieke saal \\
\hline Denominasionele affiliasie: & Gemeng, maar meestal van Afrika Onafhanklike Kerke \\
\hline Geletterdheidsvlak: & Gemiddeld tussen primêre en sekondêre skoolvlak \\
\hline
\end{tabular}

\section{Groep 8:}

\begin{tabular}{|l|l|}
\hline Kulturele groep: & Bruin Afrikaans \\
\hline Taal: & Afrikaans \\
\hline Groepgrootte: & 6-10 lede \\
\hline Gender-verspreiding: & Vroulik en manlik (gelyke verdeling) \\
\hline Ouderdomsverspreiding: & Gemiddeld > 55 jaar \\
\hline Groepgeskiedenis: & $>10$ jaar \\
\hline Rede vir bestaan: & Het ontstaan na geestelike ervaring tydens Pinksterdienste \\
\hline Self-identifisering van groep: & $\begin{array}{l}\text { Gebedsgroep; Pastorale ondersteuningsgroep; Uitreik in die } \\
\text { gemeenskap }\end{array}$ \\
\hline Ontmoetingsplek: & In kerkgebou \\
\hline Denominasionele affiliasie: & Gemeng, maar meestal van die Protestantse tradisie \\
\hline Geletterdheidsvlak: & Gemiddeld tussen primêre en sekondêre skoolvlak \\
\hline
\end{tabular}


Die agt groepe het individueel in drie van die vier fases van die empiriese studie gefunksioneer (sien verduideliking onder). 'n Interkulturele ervaring is egter in fase 3 ingebou toe die groepe met hul "partner"-groepe moes ontmoet vir 'n bespreking van die Bybelteks wat in die vorige fase individueel bestudeer is.

\subsection{Prosedure}

\subsubsection{Aanvanklike ontmoeting met groepleiers}

Om eienaarskap en deelname by die verskillende groepe te verseker, is die groepleiers na 'n aanvanklike byeenkoms genooi waar die doelwitte van die projek verduidelik is. Dit is aan die groepleiers verduidelik dat die doel van die empiriese studie nie sou wees om die dinamika van interkulturele Bybellees as sodanig te ondersoek nie, maar om te probeer vasstel of interkulturele Bybelstudie bydra tot die ontwikkeling en fasilitering van daardie voorveronderstellings wat suksesvolle interkulturele interaksie in die hand werk.

Hoewel die breë buitelyne van die prosedure aan hulle gekommunikeer is deur die projekleier, het die groepleiers die geleentheid gehad om inspraak te hê in die ontwikkeling van die fyner detail daarvan, en is hulle ook betrek in die finale keuse van 'n Bybelteks wat deur die verskillende groepe bestudeer sou word. Nadat die projekleier vyf moontlike tekste uit die Ou en Nuwe Testament gesuggereer het - tekste wat veral saamhang met die konsepte "familie" en "gasvryheid" (sien bespreking hieronder) - het die groepleiers gekies vir Lukas 11:1-13. Die groepleiers het dit fassinerend gevind dat Jesus se gelykenisse oor die vriend om middernag en die vader wat aan sy seun voorsien, in die evangelie van Lukas met die sogenaamde "Ons Vader"-gebed verbind word. Hulle het aangedui dat hulle daaraan gewoond is om die "Ons Vader" in isolasie van die gelykenisse te lees, en dat die gehele teks tot stimulerende gesprekke in die verskillende groepe sou kon aanleiding gee. Hierdie aanvanklike reaksie van die groepleiers is later ook in byna al die groepe bevestig.

'n Ander belangrike aspek wat by die aanvanklike ontmoeting met die groepleiers aandag geniet het, was die etiese aspekte van die navorsing. Die groepleiers het hul groepe se instemming tot die navorsing bevestig. Die projekleier het ook 'n ooreenkoms met die groepleiers gemaak dat geen individu of groep in die rapportering van die resultate geïdentifiseer sal word nie. Groepleiers is ook daarvan verseker dat alle groeplede na 'n afsluitingsbyeenkoms genooi sou word waar die voorlopige resultate aan hulle gekommunikeer sou word voordat dit gepubliseer word. Die afsluitingsbyeenkoms sou ook die geleentheid bied om hul interkulturaliteit met mekaar te vier. 


\subsubsection{Opleiding van navorsingsassistente}

Om vergelykbare resultate te kon kry, is drie navorsingsassistente opgelei om die projekleier met semi-gestruktureerde onderhoude en verslagdoening te help. Die assistente het die vraelyste vir die onderhoude saam met die projekleier gefinaliseer, en het ingestem tot 'n protokol vir rapportering oor die groepsessies (sien verduideliking oor fases 1 en 4 hieronder). Daar is ook besluit dat die projekleier alleen verantwoordelikheid sou neem vir die kodering van die verslae in Atlas.TI om homogeniteit in die koderingstrategie te verseker.

\subsubsection{Fase 1: Semi-gestruktureerde onderhoude}

Soos dit in 'n vorige publikasie in aanloop tot die projek verduidelik is, sou twee konsepte die spilpunte wees waarrondom die semi-gestruktureerde onderhoude ontwerp sou word. ${ }^{10}$ Die konsepte "familie" en "gasvryheid" is om die volgende redes gekies: (i) hulle word dikwels metafories verbind met kernaspekte van die Christelike geloof, (ii) die konsepte is welbekend in al drie kulturele groepe wat in die projek betrokke is, en (iii) hulle kan op verskillende lewensfere toegepas word, vanaf die persoonlike tot kerklike en publieke sfere.

Die eerste semi-gestruktureerde onderhoud met elke groep is deur 'n navorsingsassistent (of projekleier) gelei en het plaasgevind in die lokaal waarin die groepe normaalweg ontmoet. ${ }^{11}$ Die volgende struktuur is gebruik:

\section{INLEIDING / BIOGRAFIE / SELF-IDENTIFISERING}

Skop af deur iets oor julle groep te deel. Wie is julle? En hoe sien julle julself?

\section{"FAMILIE"}

Wat verstaan julle onder die term "familie"?

Hoe funksioneer 'n "familie"?

Sou julle jul onderskeie kerke as 'n "familie" beskou?

Sou julle die Suid-Afrikaanse nasie as 'n "familie" beskou? (met verwysing na Tutu se uitspraak in hierdie verband)

\section{"GASVRYHEID"}

Wat is "gasvryheid"?

Meen julle dat jul groep/kerk "gasvryheid" moet betoon?

Meen julle dat "gasvryheid" 'n kenmerk is van die Suid-Afrikaanse nasie?

\section{Sien weer Jonker (2007).}

11 In enkele gevalle het groepe besluit om fases 1 en 2 gedurende een verlengde sessie te doen. 
Die besprekings het plaasgevind in die moedertaal van die groeplede (Afrikaans of isiXhosa). Twee van die assistente kon isiXhosa praat (een as moedertaalspreker, en die ander as vlotspreker as tweede taal), en hulle is dus gevra om die sessies met die drie Xhosa-sprekende groepe te fasiliteer.

Die betrokke navorsingsassistent (of projekleier) het daarna die reaksies opgesom volgens die ooreengekome riglyne wat gedurende die opleidingsessie afgespreek is. Sleutelwoord en/of -frases is neergeskryf en 'n ryk beskrywing ("thick description") van die groeplede se reaksies is verskaf. Hierdie verslae is toe voorberei vir insluiting in die Atlas. TI databasis as 'n eerste stel primêre dokumente, maar is nie (weens etiese redes) met die "partner"-groepe gedeel nie. Die twee Xhosa-sprekende assistente het die verslae van die drie isiXhosa-groepe in of Engels of Afrikaans vertaal sodat dit ook toeganklik kan wees vir ander navorsers.

\subsubsection{Fase 2: Bybelstudie van Lukas 11:1-13}

Die groepe is versoek om 'n tweede geleentheid te reël waar hulle Lukas 11:1-13 sou bestudeer op die wyse wat hulle gewoonlik hul byeenkomste inrig. In die geval van nuutgestigte groepe is hulle versoek om aan die begin 'n kort bespreking te hê waarin hulle ooreenkom oor hoe hulle hul ontmoeting gaan struktureer, en hoe hulle met die Bybelteks kan omgaan. Groepe is ook toestemming gevra om video-opnames van die groepsessies te maak sodat hul "partner"-groepe in fase 3 aan die dinamika van hul ontmoeting blootgestel kon word. Alle groepe het hul toestemming daartoe verleen.

'n Ryke verskeidenheid modusse van hantering en interpretasie van die Bybelteks het na vore gekom in die groepsessies. Dit was merkwaardig om waar te neem hoe die modus van besigwees met die teks goed gekorreleer het met die biografiese self-beskrywings wat deur elke groep voorsien is. Daardie groepe wie se fokus op Bybelstudie as sodanig is, het verskillende maniere van teksanalise gebruik en het van verskillende vertalings, kommentare, ensovoort gebruik gemaak. Groepe wat hulself primêr as gebedsgroepe sien, het die teks as afskopplek vir hul eie gebede en intrede gebruik. Versorgingsgroepe het die teks gefynkam om suggesties te vind oor hoe hulle mekaar kan ondersteun, en hoe hulle na die gemeenskap kan uitreik.

Hoewel daardie lesings en/of interpretasies van die Bybelteks opsigself baie interessante resultate opgelewer het (soos in die video-opnames gedokumenteer), het dit nie die fokus van die analise van die huidige projek gevorm nie (soos reeds hierbo en in 'n vorige publikasie verduidelik is), ${ }^{12}$ en transkripsies van die interpretasies is dus nie in die Atlas.TI-databasis ingesluit nie.

12 Sien weer Jonker (2007). 


\subsubsection{Fase 3: Interkulturele ontmoeting met die "partner"-groep}

Die groepe is in hierdie fase aan mekaar gekoppel om sekere "kulturele pare" te vorm (soos reeds hierbo verduidelik is). Hulle is versoek om by die huis (of gewone ontmoetingsplek) van die een groep te vergader, byvoorbeeld, die een Wit Afrikaanse groep het hul Xhosa "partner"-groep by laasgenoemde se ontmoetingsplek besoek, terwyl die 'n ander Wit Afrikaanse groep hul Xhosa "partner"-groep by hul eie ontmoetingsplek ontvang het. Die derde Wit Afrikaanse groep het hul Bruin Afrikaanse "partner"-groep by laasgenoemde besoek, terwyl die tweede Bruin Afrikaanse groep hul Xhosa "partner"-groep by laagenoemde ontmoet het. Op hierdie manier is alle groepe aan mekaar se kulturele omgewing blootgestel, en het hulle die geleentheid gehad om die gasvryheid van die ander groep te beleef. Hierdie pare is op so 'n wyse uitgewerk dat alle kulturele groepe as gashere/gasvroue of as gaste opgetree het. Die gashere/gasvroue is versoek om hul gaste op so 'n wyse te ontvang as wat hulle normaalweg gaste sou ontvang.

Die ontmoeting het soos volg verloop: Elke groep het eers die geleentheid gehad om hul biografie en inligting oor self-identifisering te deel. Daarna het hulle hul lees/ interpretasie van die Bybelteks mondeling met mekaar gedeel, met 'n aantal grepe uit die video-opnames wat die assistent (of projekleier) ter toeligting vertoon het. In die geval van isiXhosa-Afrikaanse pare, het die gesprek in 'n gemeenskaplike taal, naamlik Engels, plaasgevind, of 'n konsekutiewe tolk het gehelp om die taalgrens te oorbrug. Twee van die vier ontmoetings het na die tyd 'n sosialiseringsmoment ingesluit.

\subsubsection{Fase 4: Semi-gestruktureerde onderhoud}

In die vierde fase is nog 'n semi-gestruktureerde onderhoud met elke groep volgens die volgende proforma gevoer (met die aspekte wat getoets is wat tussen hakies vermeld word):

1. Vertel iets oor jul ervaring van die gesamentlike byeenkoms. Meen julle dit was suksesvol? Of nie? Wat bedoel julle daarmee as julle sê dit was suksesvol of nie? (Ervaring van interkulturaliteit)

2. In watter opsigte is julle eenders en/of anders as die ander groep? (Ervaring van kontinuïteit en/of diskontinuïteit)

3. Het julle kennis van en insig in die ander groep verander deur die kontak? Indien wel, hoe en waarom? (Verandering in kennis en/of insig)

4. Het jul gesindheid teenoor die ander groep verander gedurende die kontak? Indien wel, hoe en waarom? (Verandering in gesindheid) 
5. Het julle gasvryheid tydens die ontmoeting beleef? Indien wel, beskryf dit? (Verandering in die verstaan van gasvryheid)

6. Meen julle dat julle tot dieselfde "familie" behoort as die ander groep? (Veranderings in die verstaan van familie)

7. Wat was julle ervaring van die hele proses wat in die projek gevolg is? (Evaluering van deelname in die projek)

Die verslae is weer eens deur die assistente opgestel op soortgelyke wyse as in fase 1, en dit is daarna as 'n tweede stel data in die Atlas.TI-databasis ingesluit.

\subsubsection{Afsluiting in plenum}

Nadat die analise gedoen is en die resultate georden is, is 'n finale plenumbyeenkoms vir alle deelnemers by die Fakulteit Teologie, Universiteit Stellenbosch, gehou. Vervoer is verskaf vir daardie groeplede wat dit nie self kon voorsien nie. Ongeveer $70 \%$ van die individuele deelnemers het die afsluitingsbyeenkoms bygewoon. Slegs een groep was glad nie verteenwoordig nie.

Die plenumbyeenkoms het drie doelwitte gehad: (i) om die interkulturele ervaring wat deur die projekbyeenkomste gefasiliteer is, te vier deur 'n kort oordenking en samesang in die verskillende tale en style van die kultuurgroepe teenwoordig; (ii) om die groeplede in te lig oor die resultate wat behaal is deur die analise van die onderhoudsverslae, en (iii) om gesamentlik te sosialiseer waartydens verversings bedien is.

Oor die algemeen is die laaste byeenkoms baie positief beleef deur alle deelnemers, en 'n hele aantal versoeke is gerig dat groepe moet voortgaan om kontak te maak met mekaar op verskillende vlakke. ${ }^{13}$

\subsection{Kodering van verslae}

\subsubsection{Koderingstrategie}

Gebaseer op ondervinding in 'n soortgelyke navorsingsprojek,,$^{14}$ is besluit om met 'n deduktiewe en induktiewe benadering te werk. Die hoofkategorieë van kodes, sowel as die eers subvlak, is vooraf gekonseptualiseer volgens die navorsingsontwerp

13 Ongelukkig was dit nie moontlik om 'n opvolgondersoek te doen oor of verdere kontak oor kulturele grense heen inderdaad hieruit voortgespruit het nie. In 'n aantal informele persoonlike gesprekke met 'n sommige deelnemers het dit duidelik geword dat individue wat mekaar later weer in die dorp of in inkoopsentrums raakgeloop het, 'n band tussen hulle gevoel het as gevolg van hul gedeelde ervaring.

14 Sien De Wit in De Wit et al. (2004:395-434). 
van die empiriese studie. Die kodes wat egter in elke kategorie gebruik is, is eers geformuleer gedurende die koderingsproses. Die rykheid van die materiaal het daarom die heuristiese proses op interaktiewe wyse geïnformeer.

Sestien verslae (twee stelle van agt elk) is geanaliseer. 'n Vergelyking binne elke groep het interessante kontinuïteite en diskontinuïteite tussen groepe na vore gebring. Die doel was egter om die verslae van die eerste stel (onderhoud voor die interkulturele ontmoeting) te vergelyk met die tweede stel (onderhoud na die interkulturele ontmoeting). Gebaseer op die teoretiese bespreking wat in 'n vorige publikasie aangebied is, is die volgende "voor/daarna"-patrone as betekenisvol vir die ondersoek beskou: (i) 'n verandering in kennis van die ander; (ii) 'n verandering in motivering om grense te oorskry; (iii) 'n verandering in vaardigheid om oor grense heen te kommunikeer; (iv) 'n verandering in gesindheid teenoor die ander; en (v) prominente en herhalende temas.

\subsubsection{Kodes en kodefamilies}

Die volgende hoofkode-families is onderskei:

01 BIOGRAFIESE DATA

02 VERSTAAN VAN "FAMILIE”

03 VERSTAAN VAN “GASVRYHEID”

04 ROL GEDURENDE INTERKULTURELE ONTMOETING (FASE 3)

05 ERVARING VAN INTERKULTURELE ONTMOETING (FASE 3)

06 (DIS)KONTINUITEIT MET “PARTNER”-GROEP

07 KENNIS VAN DIE ANDER

08 GESINDHEID TEENOOR DIE ANDER

09 ERVARING VAN GASVRYHEID

10 ERVARING VAN FAMILIE

\section{ALGEMENE EVALUERING VAN DEELNAME AAN DIE PROJEK}

Die response wat deur families 01, 02 en 03 gekodeer is, is ingewin deur die eerste semi-gestruktureerde onderhoud wat met elke groep voor die interkulturele blootstelling gehou is, terwyl families 05 tot 10 die resultaat was van die tweede semi-gestruktureerde onderhoud na die interkulturele blootstelling. Behalwe die twee sleutelkonsepte "familie" en "gasvryheid" is die voorwaardes vir interkulturele kommunikasie wat in die teoretiese refleksie in die projek beklemtoon is, as heuristiese sleutels gebruik vir die analise van die mate van transformasie wat plaasgevind het (sien veral kodefamilies 07 en 08). Kodefamilies 05 en 06 wat die reaksie op die interkulturele ontmoeting gedokumenteer het, is gekruiskontroleer teen die rol van die groep (sien kodefamilie 04 - as gasheer/-vrou of as gas) om vas 
te stel of die konteks waarin die ontmoeting plaasgevind het, 'n invloed uitgeoefen het op die ervaring.

\subsubsection{Kruistabulering}

Die biografiese data is nie gekruistabuleer met die ander reaksies nie, omdat die huidige kwalitatiewe analise nie ten doel gehad het om daardie korrelasies te maak nie, en aangesien die steekproef te klein was om betekenisvolle afleidings te maak. Die interpretasie van die data het daarom nie die pretensie om tipiese ervarings en/ of reaksies van die verskillende kultuurgroepe te identifiseer of voorspel nie.

\section{OPSOMMING VAN WAARNEMINGS}

Die kwalitatiewe analise van die data het baie interessante en ryk resultate opgelewer. Die empiriese oefening het weer beklemtoon dat 'n kleinskaal kwalitatiewe studie nie noodwendig verteenwoordigende data van enige aard oplewer nie, maar dat dit 'n dieper verstaan van gemeenskapsinteraksie kan fasiliteer. Voordat die bevindings in die volgende afdeling aangebied word, word enkele prominente waarnemings hier bespreek.

\subsection{Prominente en herhalende temas}

Die analise van die verslae van die eerste semi-gestruktureerde onderhoude het 'n baie ryk verstaan van die konsepte "familie" en "gasvryheid" na vore laat tree. 'n Totaal van 32 verskillende kodes is gebruik om die groepe se verstaan van "familie" te beskryf, en die meerderheid van hierdie kodes het meer as een keer voorgekom. Die definisie van "familie" wat die meeste voorgekom het, was die volgende:

- Plek waar onderlinge ondersteuning geld (5 response);

- Plek waar probleme gedeel kan word (5 response);

- Plek waar verskeidenheid sieninge moontlik is (5 response);

- Verhouding gebou op inagname van mekaar (5 response);

- Verhouding gebou op liefde (5 response);

- Bloedband (4 response).

Hoewel slegs twaalf kodes nodig was om die groepe se verstaan van "gasvryheid" te dokumenteer, kan 'n prominente herhaling van temas waargeneem word. Die volgende is die prominentste voorbeelde:

- Sorgdra vir mekaar (8 response);

- Maak ruimte vir mekaar (8 response); 
- Bereidheid om van jouself te gee (7 response);

- Verwant aan aanvaarding en liefde (7 response);

- Vertroue tussen mense nodig (4 response).

Hierdie response uit die eerste onderhoude het aan die ondersoekspan bevestig dat die sleutelkonsepte "familie" en "gasvryheid" goedgekose was vir die doel van die empiriese studie. Deelnemers kon goed assosieer met hierdie konsepte, en hulle was nuttige heuristiese gereedskap waarmee die deelnemers se ervaring van interkulturaliteit in die Suid-Afrikaanse samelewing ondersoek kon word. Die volgende subafdeling voorsien 'n beskrywing van hoe die analise van die SuidAfrikaanse situasie in terme van hierdie konsepte plaasgevind het.

\subsection{Ervaring van die Suid-Afrikaanse nasie in terme van "familie" en "gasvryheid" (voorafgaande aan interkulturele ontmoeting)}

Toe die deelnemers in die eerste semi-gestruktureerde onderhoud (d.w.s. voor die interkulturele blootstelling) gevra is of hulle die Suid-Afrikaanse nasie as ' $n$ familie sien, het die oorgrote meerderheid negatief daarop gereageer. Slegs drie kodes was nodig om enkele positiewe response te dokumenteer. Vyf response (dwarsoor die spektrum van biografiese profiele) het aangedui dat die Suid-Afrikaanse nasie wel 'n familie is, omdat die gedeelde Christelike geloof verdeeldheid en grense oorbrug. Een persoon het aangedui dat ons ' $n$ familie is op grond van ons gedeelde ervaring in die land, terwyl 'n ander geïsoleerde respons aangedui het dat ons 'n familie is, omdat ons verwelkomend teenoor vreemdelinge en buitestaanders is. Twee verdere positiewe kodes was nodig om twee individuele response te dokumenteer waarin die droom dat Suid-Afrika 'n familie kan wees, tot uitdrukking gebring is ("dit behoort 'n ideaal vir die Suid-Afrikaanse nasie te wees om soos 'n familie te wees"; "gebed kan versoening bring"). Die oorweldigende gees van al die besprekings oor hierdie onderwerp was egter taamlik negatief. Tien verdere kodes was nodig om uitdrukking te gee aan die feit dat die meeste nie die Suid-Afrikaanse nasie as 'n familie ervaar nie:

- SA nasie nie altyd familie nie (5 response);

- Apartheidsverlede bring nog skeuring (4 response);

- Kulturele verskille bring steeds skeiding (3 response);

- Interne verhoudings moet verbeter (3 response);

- Onder huidige regering ontwikkel weer skeiding (2 response);

- Denke in terme van velkleur bring nog skeiding (1 respons); 
- Vertrouensbreuk teenoor swartmense (1 respons);

- Kopskuiwe nog nodig (1 respons);

- Nie genoeg gemeenskaplikhede (1 respons);

- Gebrek aan kennis vanmekaar (1 respons).

Dieselfde patroon het na vore getree uit die bespreking of die Suid-Afrikaanse nasie wel gasvry is. 'n Minderheid kodes het positiewe response uitgedruk ("toeriste ervaar Suid-Afrikaners normaalweg as gasvry"; "daar is voorbeelde van gasvryheid te midde van arm toestande"; "om mekaar te ken, verdryf vrees"; "om bereid te wees om mekaar te help, verdryf vrees"). Van hierdie positiewe response het selfs ook na vrees verwys (sien die bespreking hieronder). Die negatiewe response op hierdie vraag is deur die volgende gekodeer:

- Vrees belemmer gasvryheid (10 response);

- Wantroue belemmer gasvryheid (10 response);

- Gebrek aan ubuntu ${ }^{15}$ belemmer gasvryheid (3 response);

- Mense wil nie uitgedaag wees nie (2 response);

- Individualisme belemmer gasvryheid (2 response);

- Gasvryheid moet perke hê! (2 response);

- Gasvryheid gaan nie oor tot dade (2 response);

- Gebrek belemmer gasvryheid (2 response);

- Sosio-ekonomiese verskille belemmer gasvryheid (1 respons);

- Politiek belemmer gasvryheid (1 respons);

- Gasvryheid slegs binne eie kultuurgroep (1 respons).

15 Die term ubuntu weerspieël die Suider-Afrikaanse etiek of humanistiese filosofie. Die term word dikwels met die Nguni-spreuk "umuntu ngumuntu ngabatu" (betekenis: 'n persoon is 'n persoon deur ander persone) in verband gebring. Daar is baie verskillende definisies wat vir die term aangebied word, en verskillende weergawes van die ontstaan daarvan, word aangebied. Vgl. die goeie opsommings in Gade (2011 en 2012). Desmond Tutu het ubuntu eenkeer soos volg beskryf: "One of the sayings in our country is Ubuntu - the essence of being human. Ubuntu speaks particularly about the fact that you can't exist as a human being in isolation. It speaks about our interconnectedness. You can't be human all by yourself, and when you have this quality - Ubuntu - you are known for your generosity. We think of ourselves far too frequently as just individuals, separated from one another, whereas you are connected and what you do affects the whole World. When you do well, it spreads out; it is for the whole of humanity" [vgl. http://en.wikipedia.org/wiki/Ubuntu (philosophy)]. 
Die bostaande voorbeelde het getoon hoe prominent die rol van vrees in die response van deelnemers was. Die volgende aanhalings weerspieël die besordheid van mense oor hierdie kwessie:

- Vrees hou mense dikwels nog apart;

- Iemand vertel van die voorval toe 'n vrou naby die "Bantoe-buurt" Khayelitsha met haar kar gaan staan het. Sy was baie bang. Almal het by haar verbygery totdat 'n kar met twee swart mans by haar gestop het;

- Groeplede gesels 'n ruk oor die vrees vir swartmense wat nog by baie bruinmense bestaan;

- Iemand noem dat dit ook lyk of vrees in die wit gemeenskap leef, omdat omtrent almal deesdae vir hulself hoë mure om hul huise bou;

- Gasvryheid in die Suid-Afrikaanse nasie sal beteken dat ons hierdie vrese moet afbreek en mekaar moet leer vertrou;

- There are also incidents of xenophobia, which is unfortunate;

- Ons vrees eerder ons medemens as om om te gee;

- Vlugtelinge kom na ons weens slegte omstandighede maar ons hanteer hulle ook meestal sleg omdat ons bang is hulle vat ons werk;

- Baie meer mense is sekuriteitsbewus en hoe hoë heinings skei mense van mekaar;

- Om welwillendheid en gasvryheid in ons land te beoefen is op die huidige tydstip moeilik, dis 'n risiko om iemand op te laai of in jou huis toe te laat.

Die onderhoude wat voorafgaande aan die interkulturele ervaring gevoer is, het dus 'n hoë vlak van multikulturele bewustheid vertoon, maar lae vlakke van interkulturele waardering. Die prominensie van vrees en wantroue het ons hipotese bevestig dat Suid-Afrikaners reeds ver gevorder het sedert 1994 in die erkenning van die multikulturaliteit van die samelewing. Die aanvaarding van multikulturaliteit as 'n bate, en die bevordering van interkulturaliteit laat egter nog veel te wense oor. Die verlede is steeds met ons, en kulturele verskille veroorsaak steeds verdeling in die samelewing.

\subsection{Ervaring van interkulturele ontmoeting}

Die interkulturele blootstelling was die volgende aspek wat aandag gekry het. Blootstelling het op drie vlakke geskied: (i) blootstelling aan mekaar; (ii) blootstelling aan mekaar se lees/interpretasie van Lukas 11; en (iii) blootstelling aan mekaar se 
leefkonteks (vier van die agt groepe moes grense oorsteek om in hul "partner"groepe se leefkontekste gehuisves te word). Hoewel sommige gasgroeplede negatief gereageer het op die blootstelling - wat gewissel het van aanvanklike huiwering tot die wegbly van die blootstellingsbyeenkoms ${ }^{16}$ - het die meerderheid (selfs sommige van diegene wat aanvanklik huiwerig was) baie positief gereageer toe hulle agterna (in fase 4) oor hul ervaring uitgevra is. 'n Ryke verskeidenheid redes vir die positiewe ervaring is verskaf. Die kodes hieronder som hul motiverings op:

- Spontaniteit;

- Is verruim deur die andersheid;

- Kon ander gaan besoek;

- Liefde en toegeneentheid;

- Eenheid/geloof/liefde oor grense heen;

- Feit dat hulle ons besoek het;

- Opgeruimdheid van ander groep;

- Kon belangstellings/lewens deel;

- Ontmoetingsgeleentheid;

- Gemeenskap het ontstaan;

- Respek vir ander groep se Christelike getuienis;

- Kon bid vir mekaar;

- Wedersydse vertroue;

- Bemoedig/versterk/gelukkig gemaak;

- Openlike gesprek;

- Het ander as gelykwaardiges ontmoet;

- Lekker gesprek gevoer;

- Kon mekaar leer ken;

- Kon baie leer by ander;

- Gees was tussen ons.

16 Hoewel lede wat gekant was teen die interkulturele blootstelling, en veral teen die idee om hul "partner"-groep in laasgenoemde se konteks te besoek, nie hul gesindheid en reaksie teenoor die navorsingspan verduidelik het nie, het persoonlike onderhoude met die groepleiers sommige van die motiewe waarom party gekies het om weg te bly, onthul. Die kwessie van vrees het sterk hierin gefigureer. 
Wat merkwaardig was van hierdie response is dat hulle oor die kulturele spektrum van deelnemende groepe voorgekom het, ongeag van die rol wat die groep vervul het (as gaste of gasvroue/gashere).

\section{4 (Dis)kontinuïteite waargeneem}

Die groepe is gevra om hul eie positiewe ervarings in terme van die ooreenkomste en verskille tussen hulself en die ander groep te analiseer. Die volgende kontinuiteite tussen hulself en hul "partner"-groepe is genoem:

- Kan aansluiting vind bymekaar;

- Almal lief vir die Here;

- Erns met Gods Woord;

- Ywer vir die Here;

- Liefde vir mekaar;

- Gemeenskaplike gebedsbetrokkenheid by nood;

- Praat oor dieselfde inhoude;

- Gedeelde humorsin;

- Afrikaans 'n samebindende faktor. ${ }^{17}$

Die lys van verskille wat deur deelnemers opgemerk is, is lank:

- Verskillende (sosio-ekonomiese) omstandighede;

- Verskillende benaderings;

- Verskillende engagement met ervaringswêreld;

- Verskillende plekke van samekoms;

- Verskillende maniere van sit; ${ }^{18}$

- Verskil in spontaniteit;

- Verskil in kinderlike oorgawe;

- Verskil in selfverstaan as groep;

17 Laagenoemde respons kom spesifiek van iemand wat in die kulturele paar "Bruin Afrikaans - Wit Afrikaans" deelgeneem het.

18 Hierdie opmerking het na vore gekom vanuit die "partner"-groep van 'n groep waar mans en vroue apart sit tydens byeenkomste. 
- Verskillende sangkultuur;

- Verskillende kleredrag;

- Verskillende samestelling in terme van geslag;

- Verskil in ras;

- Verskille in lyftaal;

- Taalverskille;

- Verskillende familiesamestelling;

- Gebed speel verskillende rolle.

Wat nie in hierdie gekodeerde response waargeneem kan word nie, is egter die waardering vir, en self fassinering met die verskille wat weerspieël is in die liggaamstaal en toon van groepe tydens die terugvoersessies. Verskille is erken en gelys, maar met waardering en respek vir "die Ander".

\subsection{Veranderings waargeneem}

Die tweede semi-gestruktureerde onderhoud het die groepe getoets vir enige veranderings wat waargeneem is. Twee vrae is gevra om terugvoer hieroor te bekom. Die vrae was:

- Het julle kennis van en insig in die ander groep verander deur die kontak? Indien wel, hoe en waarom? (Verandering in kennis en/of insig)

- Het jul gesindheid teenoor die ander groep verander gedurende die kontak? Indien wel, hoe en waarom? (Verandering in gesindheid)

Die vrae hou verband met die aanduidings in die literatuur dat interkulturele kommunikasie deur hierdie faktore gefasiliteer word. Kool (2004) het byvoorbeeld sekere omstandighede wat verandering van perspektief in interkulturele kommunikasie veroorsaak, geïdentifiseer in haar analise van leesverslae wat in die internasionale interkulturele Bybelleesprojek "Through the Eyes of Another" (geïnisieer by die Vrije Universiteit, Amsterdam) opgestel is. Die eerste faktor wat sy noem, is "Attitude toward the partner group". Sy maak die volgende stelling: "The most important condition for successful intercultural communication is the attitude people have when they enter the process. This attitude can make or break the process ..." (2004:363). De Wit (2004:506-507) bied ook 'n kort samevatting aan van die basiese voorwaardes wat moet geld om suksesvolle interkulturele Bybelstudie te kan fasiliteer: 
Attitude: Successful interaction requires a basic attitude of openness, trust, vulnerability, and willingness to criticize oneself and to see one's own faith insights as relative. This attitude applies to the reading process of the group itself as well as to the interaction with the partner group. Confrontation is allowed, but it must be based on trust. Not every type of motivation is productive. Motivation especially focused on acquiring new knowledge, focused on challenges, turns out to be enriching ....

Knowledge: The group needs basic knowledge of how cultures operate. Differences between groups soon become apparent, but it requires knowledge to see how these cultural differences can be identified and understood ....

Insight: Insight into the group's own reading attitude and interpretation method is also important. This insight enables participants to discover the connection between the method and the results of their interpretation and that of the partner group ...

Alle groepe het oorweldigend positief gereageer op die twee vrae oor veranderings wat bemerk is. In terme van "gesindheid" is die volgende kodes gebruik om uitdrukking te gee aan die rykheid van die response:

- Waardering verhoog;

- Besef van ooreenkomste met hulle;

- Bybel verander gesindheid;

- Bring groter spontaniteit en openheid;

- Besef van nabyheid;

- Wanbeelde van ander verander;

- Groter vertroue;

- Bring ook besef van verskille;

- Kan by die ander leer.

Die veranderings in kennis en insig is op die volgende maniere beskryf:

- Vooroordele verdwyn (8 response);

- Leer ken mekaar se manier van doen (5 response);

- Toename in respek vir toewyding van die ander (4 response);

- Kennis van ander se leefwêreld;

- Ontdek gemeenskaplike (geestelike) behoeftes; 
- Groter insig in ander se geloof/aanbidding;

- Meer tyd/blootstelling nodig;

- Toename in waardering vir die ander se integriteit;

- Kennis bring groter vrymoedigheid;

- Ontdekking van mekaar as mense;

- Kan nou met die ander kommunikeer.

Die kode wat die meeste response verteenwoordig het, was die een waarin groeplede se erkenning dat hul vooroordele teenoor hul "partner"-groep(lede) verdwyn het. Die volgende aanhalings reflekteer die rykheid van die data hieroor:

- Hulle het nou besef dat, hoewel sommige gedink het dat die witmense hul sal slimmer hou, hulle eintlik gemaklik met hulle kon kommunikeer;

- Die blootstelling aan die witmense het gehelp om hul eie vooroordele af te breek;

- We always think of crime when we think about townships, but there are good people as well;

- They did not show over self-confidence which can be intimidating. We expected them to be overly self-confident;

- They seemed to be a bit shy to talk during reporting while we thought they will be saying a lot of things that we should learn;

- Ons het nooit regtig geweet hoe blankes oor God en oor geloof dink nie. Ons het altyd gedink dat hulle baie anders as ons is en allerhande goed doen en glo wat ons nie het nie;

- Ons het hulle as opreg leer ken en hulle het nie maar net voorgegee in hulle houding teenoor ons nie, hulle was nie "whitewashed" nie;

- Almal sit met stereotipes van ander mense; vir die X-groep was hulle kennis, en dus verwagting, van die groep grootliks gestempel deur hul verhouding met swartmense in hoofsaaklik werkverband. ${ }^{19} \mathrm{Al}$ sou hul ook daar gelykes wees, is afstand tog altyd ervaar. Die moeite wat die groep gedoen het om op 'n Sondagmiddag te kom en die manier waarop hulle aangetrek was, het heeltemal 'n ander indruk gebring.

19 Die persoon het hiermee verwys na die konteks waarin huishulpe (hoofsaaklik vanuit die swart gemeenskappe) vir witmense in hul huise werk. 


\subsection{Ervaring van die Suid-Afrikaanse nasie in terme van "familie" en "gasvryheid" (na afloop van die interkulturele ontmoeting)}

$\mathrm{Na}$ afloop van die interkulturele ontmoeting, in die tweede semi-gestruktureerde onderhoud, is die groepe weer eens oor hul ervaring van die Suid-Afrikaanse nasie in terme van die konsepte "familie" en "gasvryheid" getoets. Dit was baie interessant om waar te neem dat 'n betekenisvolle skuif plaasgevind het vanaf hul aanvanklike verstaan van en response op hierdie konsepte.

Die volgende kodes druk die ervarings van gasvryheid uit na afloop van die interkulturele ontmoeting:

- Het liefde en vriendelikheid ervaar (8 response);

- Skep openheid (8 response);

- Gemeenskaplike geloof skep gasvryheid (4 response);

- Ander het hul wêreld vir hulle oopgestel (4 response);

- Skep gevoel van inpas;

- Ontdek gemeenskaplikhede.

In reaksie op die vraag waarom hulle 'n gevoel van "familie" saam met die ander gehad het, het die volgende kodes na vore getree:

- Deel Christus met mekaar (8 response);

- Saam medewerkers van Christus;

- Ontmoeting versterk gevoel van familie;

- Kerklike bande maak ons familie;

- Ooreenkomste meer as verskille;

- Is almal beelddraers van God.

Die baie positiewe response het dramaties gekontrasteer met die redelik negatiewe verstaan van die Suid-Afrikaanse nasie in terme van "familie" en "gasvryheid" wat waargeneem is in die eerste semi-gestruktutreerde onderhoud voor die interkulturele blootstelling. Hoewel die projek slegs 'n eenmalige interkulturele Bybelstudieontmoeting ingesluit het, kan 'n mens met vertroue vanuit die bogenoemde data aandui dat betekenisvolle transformasie in alle groepe plaasgevind het, asook in individuele groeplede, met betrekking tot hul openheid teenoor en begrip van "die Ander". 


\section{OPSOMMING VAN BEVINDINGS}

\section{1 'n Gebrek aan interkulturaliteit in die Suid-Afrikaanse samelewing}

Die hipotese wat in hierdie navorsing getoets is, is duidelik bevestig. Hoewel daar 'n bewustheid en selfs aanvaarding van multikulturaliteit in die Suid-Afrikaanse samelewing is, ontbreek interkulturaliteit nog. Daar is geargumenteer dat die konsepte van "familie" en "gasvryheid" as toetsinstrumente vir die verstaan en belewing van interkulturaliteit in die samelewing gebruik kan word. Hoewel all deelnemende groepe'n baie ryk verstaan van hierdie konsepte gehad het en die waardes van familie en gasvryheid hoog geag het in hul private sfere, het hulle 'n inkongruensie beleef tussen hierdie begrippe en hul belewing van die Suid-Afrikaanse nasie. Die data wat hierbo beskryf is, het getoon dat die belewing van deelnemers voroafgaande aan die interkulturel ontmoeting gedomineer is deur vrees en 'n gebrek aan kennis van "die Ander". Die ryke aanhalings oor hierdie kwessies het aangedui dat vrees in al die deelnemende kulturele groepe manifesteer, hoewel in verskillende vorme. Vrees dat vreemdelinge hul werk sal afvat, vrees dat jou eiendom gesteel kan word, vrees dat ander jou lewe in gevaar kan stel, vrees dat jy verneder mag word: hierdie is almal verskyningsvorms van 'n dominante faktor wat interkulturaliteit in die samelewing belemmer. Dit het verder duidelik geword dat vrees dikwels verband hou met 'n gebrek aan kennis van "die Ander". Vele wanopvattings oor "die Ander" het na vore getree tydens die proses van interkulturele blootstelling. Dit is vasgestel dat blootstelling aan "die Ander" op die basis van 'n gemeenskaplike Bybelstudie, asook 'n uitbreiding van kennis van "die Ander" bydra om vrees af te breek. Die afbreek van vrees fasiliteer weer die ervaring van interkulturaliteit.

\section{2 'n Gemeenskaplike faktor}

Die gemeenskaplike Bybelstudie moenie in die proses onderskat word nie. Die oefening is nie bloot as ondersoekinstrument in die empiriese studie gebruik nie. Dit het eerder as instrument gefunksioneer wat die gemeenskaplike deler van die Christelike geloof beklemtoon het. ${ }^{20}$ In die konseptualisering van die projek is die waarde en potensiaal van hierdie gemeenskaplike deler tussen al die verskillende kulturele en rassegroepe in Suid-Afrika besef. Die deel van die groepe se lees/

20 Volgens die 2001 sensus bely $79.7 \%$ van die Suid-Afrikaanse bevolking dat hulle Christene is. 'n Mens sou kon aanneem dat dieselfde potensiaal vir interkulturaliteit ook in ander geloofstradisies in Suid-Afrika bestaan. Islam (met 1.5\%) en Hinduïsme (met 1.3\%) het egter hul steun binne spesifieke kultuurgroepe, en hulle sny dus nie oor kulturele grense in dieselfde mate as die Christendom nie. 
interpretasies van Lukas 11 met mekaar is daarom met opset in die interkulturele blootstelling ingesluit.'n Mens moet dus erkenning gee aan die feit dat die ontdekking deur deelnemers van hul gedeelde geloof die gunstige omstandighede geskep het waarin die interkulturele ontmoeting gefasiliteer kon word. Sonder hierdie gemeenskaplike deler sou die ervaring van interkulturele blootstelling waarskynlik heeltemal anders gewees het. Hierdie punt beklemtoon dus hoe belangrik dit is om te besef dat die Bybel as Skriftuur van die Christelike gemeenskap 'n kragtige transformatiewe instrument in die Suid-Afrikaanse samelewing kan wees. Interkulturele Bybelstudie-oefeninge moet dus oorweeg word as altenatiewe wyses waarop interkulturaliteit in Suid-Afrika gefasiliteer kan word.

\section{3 'n Inklusiewe hermeneutiek}

Die groepe is by die eerste sessie ingelig dat hulle die geleentheid sou hê om Lukas 11 te lees/interpreteer soos hulle gewoond is om te doen in hul groep, maar dat hulle dan ook gevra gaan word om hul lees/interpretasie met hul "partner"-groep by 'n georganiseerde ontmoeting te deel. Hierdie strategie is doelbewus gekies om interaksie te bewerkstellig tussen wat Kessler (2004:452-459) bipolêre en multipolêre verstaan genoem het. Die lees binne die eie groep het volgens eie konvensies, maar ook eie teologiese oortuigings, plaasgevind. Die interkulturele ontmoeting het egter die geleentheid geskep om hul lees van die teks in 'n interkulturele omgewing te deel, en daarvoor in te staan. Die hermeneutiese dinamika wat deur hierdie interaksie geskep is, het onmiddellik die binne- of eksklusiewe hermeneutiek van elke groep verander tot 'n inklusiewe hermeneutiek. Die groeplede moes reageer in terme van die kontinuïteite en diskontinuïteite van hul onderskeie interpretasies van die teks. Maar, dit het alles gebeur binne die konteks van die gemeenskaplike Christelike geloofsoortuiging. Interkulturele interaksie binne die konteks van 'n gemene deler het die ruimte geskep waarbinne 'n inklusiewe hermeneutiese verstaan kon begin ontwikkel, en waarbinne 'n beweging van 'n bipolêre na 'n multipolêre verstaan kon plaasvind. ${ }^{21}$

\subsection{Die belang van grensoorskryding}

In die bogenoemde punt het die belang van die kwessie van grensoorskryding reeds na vore gekom. Grensoorskryding is nie net bewerkstellig deur die multikulturele paring van Bybelstudiegroepe nie, maar ook deur die fisiese grensoorskryding van een groep wat 'n ander in laasgenoemde se konteks gaan besoek het. Dit was 'n betekenisvolle strategie, gegewe die Suid-Afrikaanse konteks waar, hoewel nie meer

21 Sien ook Jonker $(2001,2005,2008)$. 
politieke oorwegings nie, maar ekonomiese werklikhede mense steeds apart hou. Mense, selfs nie Christine nie, ken nie mekaar se fisiese leefwêrelde nie. Hierbo is aangedui hoe belangrike faktor vrees was in die daad van grensoorskryding. In een geval het slegs drie lede van die gasgroep opgedaag om saam met die projekspan na die "partner"-groep se konteks in een van die swart "townships" te gaan. Interkulturaliteit het ook fisiese dimensies. Die impak van die interkulturele ervaring was soveel groter vir diegene wat grense oorskry het en hul eie veilige ruimtes verlaat het om die leefwêreld van "die Ander" binne te gaan. 'n Toename in kennis van "die Ander" asook veranderings in gesindheid teenoor die ander is geweldig aangehelp deur die fisiese grensoorskryding wat deel gevorm het van die empiriese studie. ${ }^{22}$

\subsection{Om 'n familie te word}

Die metafoor wat 'n leidende rol in die navorsing gespeel het, was die ryke verstaan van "familie" en "gasvryheid" wat by die groeplede bevind is. Dit was merkwaardig om in die projek te beleef hoe groepe by die eerste onderhoud meer as gewillig was om hul persoonlike sfere en die lewe van die kerk/gemeente in terme van hierdie begrippe te beskryf, maar weerstand gehad het om dieselfde te doen met betrekking tot die Suid-Afrikaanse samelewing. Die oorweldigende negatiewe respons hieroor was tekenend van die gebrek aan interkulturaliteit in die samelewing. Die veranderings in kennis van "die Ander" en gesindheid teenoor "die Ander" wat in die projek gefasiliteer is, het ten minste by deelnemers die perspektief laat ontstaan dat die Suid-Afrikaanse nasie ook inderdaad tekens toon van familiewees. Die gemene deler van Christelike gemeenskap, die besef dat vele van hul vrese onwerklik en irrasioneel is, en hul besef van 'n gedeelde lot, het die bewustheid dat die SuidAfrikaanse nasie 'n familie kan wees, laat groei.

\section{KONKLUSIE}

Hoewel hierdie projek data-inwinning vanuit 'n kleinskaalse waarneming in 'n beperkte aantal Bybelstudiegroepe gedoen het en ander beïnvloedende faktore nie in ag geneem is nie, het die kwalitatiewe analise van die ryke terugvoer vanuit die twee semi-gestruktureerde onderhoude die navorsers in staat gestel om daardie diep gevoelens en houdings te peil wat deelnemers se ervaring van interkulturaliteit weerspieël. Met die hulp van die twee konsepte "familie" en "gasvryheid" - konsepte waarvan die verstaan oor kulturele grense sny, en wat vanaf die familiesfeer na die kerk en samelewing uitgebrei kan word - kon die navorsingspan die "voor-daarna" patrone met betrekking tot kennis en insig van, en gesindheid teenoor "die Ander"

22 Sien ook Riches (2004). 
peil. Hoewel daar 'n prominente bewussyn van die multikulturaliteit van die SuidAfrikaanse samelewing voor die interkulturele intervensie van die navorsingsprojek was, is hierdie multikulturaliteit hoofsaaklik beleef in terme van verskille met "die Ander". Die interkulturele ontmoeting op basis van 'n gedeelde Bybelstudie het betekenisvolle veranderings teweeggebring. Die veranderings wat waargeneem is, het nie net beklemtoon hoe belangrik interkulturele blootstelling is nie, maar ook hoe waardevol dit in die Suid-Afrikaanse samelewing is dat die Christelike geloof dwarsoor kulturele en rassegrense strek..$^{23}$

Die projek het geen pretensie dat die samelewing daardeur betekenisvol verander is nie. Slegs 'n klein aantal mense is betrek en geen opvolgbyeenkomste is gereël nie (behalwe die afsluiting in plenum). 'n Mens kan selfs twyfel uitspreek of die transformasie wat deur die projek bewerkstellig is, volhoubaar gemaak kan word. Die projek het egter wel duidelik die instrument van interkulturele Bybelstudie as transformatiewe krag in die samelewing bevestig. Dit het ook die belang van 'n stelling wat reeds in die teoretiese fase van die projek gemaak is, beklemtoon: "Interculturality is ... a personally driven strategy to overcome 'othering"' (vgl. Jonker 2007:483). Kerke, maar ook regerings- en nie-regeringsorganisasies, sou goed doen om van hierdie waardevolle instrument kennis te neem wat kan bydra daartoe om die Suid-Afrikaanse samelewing in 'n "familie" te verander.

\section{BIBLIOGRAFIE}

BABBIE, E. 2004. The Prctice of Social Research. Belmont: Wadsworth. $10^{\text {th }}$ edition.

DE WIT, J.H. ET AL. (EDD.) 2004. Through the eyes of another. Intercultural reading of the Bible. Elkhart, Indiana: Institute of Mennonite Studies.

GADE, C.B.N. 2011. The Historical Development of the Written Discourses on Ubuntu. South African Journal of Philosophy 30(3):303329.

--- 2012. What is Ubuntu? Different Interpretations among South Africans of African Descent. South African Journal of Philosophy 31(3):484-503.

JONKER, L.C. 2001. Towards a 'communal' approach for reading the Bible in Africa. In: M.N. Getui et al. (edd.), Interpreting the Old Testament in Africa (Nairobi: Acton Press), pp. 77-88.

23 Vir 'n deeglike bespreking van 'n hermeneutiek van transformasie, sien Sarojini Nadar (2006) se bespreking van Gerald West se werk in hierdie verband. 
--- 2005. 'Contextuality' in (South) African Exegesis: Reflections on the Communality of our Exegetical Methodologies. OTE 18(3):637-650.

--- 2006. From Multiculturality to Interculturality: Can Intercultural Biblical Hermeneutics be of any Assistance? Scriptura 91:19-28.

--- 2007. On Becoming a Family: Multiculturality and Interculturality in South Africa. $\operatorname{Exp} T$ 118(10):480-487.

--- 2008. Living in different worlds simultaneously. Or: A plea for contextual integrity. In: G. West and J.H. de Wit (edd.), African and European Readers of the Bible in Dialogue (Leiden: Brill), pp. 107-119.

KESSLER, R. 2004. From bipolar to multipolar understanding. Hermeneutical consequences of intercultural Bible reading. In: J.H. de Wit et al. (edd.), Through the eyes of another. Intercultural reading of the Bible (Elkhart, Indiana: Institute of Mennonite Studies), pp. 452-459.

KOOL, M. 2004. Intercultural Bible reading as a practical setting for intercultural communication. In: J.H. de Wit et al. (edd.), Through the eyes of another. Intercultural reading of the Bible (Elkhart, Indiana: Institute of Mennonite Studies), pp. 360-376.

NADAR, S. 2006. 'Hermeneutics of Transformation?' Critical Exploration of the Model of Social Engagement between Biblical Scholars and Faith Communities. Scriptura 93:339-351.

RICHES, J. 2004. Intercultural hermeneutics. Conversations across cultural and contextual divides. In: J.H. de Wit et al. (edd.), Through the eyes of another. Intercultural reading of the Bible (Elkhart, Indiana: Institute of Mennonite Studies), pp. 460-476.

TUTU, D. 2004. God has a dream: A vision of hope for our time. Johannesburg: Rider.

\section{TREFWOORDE}

Empiriese Hermeneutiek

Multikulturaliteit

Interkulturaliteit

Bybelse Hermeneutiek

Suid-Afrikaanse samelewing 
JONKER, LOUIS

\section{KEY WORDS}

Empirical Hermeneutics

Multiculturality

Interculturality

Biblical Hermeneutics

South African society 